\title{
Further evidence for fungivory in the Lower Devonian (Lochkovian) of the Welsh Borderland, UK
}

\author{
Dianne Edwards ${ }^{1} \cdot$ Lindsey Axe $^{1} \cdot$ Jennifer L. Morris ${ }^{1}\left[\mathbb{D} \cdot\right.$ Lynne Boddy $^{2} \cdot$ Paul Selden $^{3,4}$
}

Received: 20 March 2019 / Accepted: 4 November 2019 / Published online: 29 January 2020

(c) The Author(s) 2020

\begin{abstract}
The recent demonstrations that widespread mid-Palaeozoic Prototaxites and other nematophytes had fungal affinities indicate that terrestrial fungi were important elements in carbon cycling in the Early Devonian. Here, we provide evidence for their participation in the recycling of nutrients by early terrestrial invertebrates. Evidence is in the form of coprolites, both those associated with nematophytes or containing their fragmentary remains. Cylindrical coprolites consistently associated with fungal mats are placed in a new ichnospecies, Bacillafaex myceliorum. Their contents are granular to amorphous, suggestive of complete digestion of the ingested hyphae, with the inference of possession of chitinases in the digestive tracts of the consumers. A further single example comprises a cluster of cylindrical bodies attached to the lower surface of a Nematothallus fragment. Here, homogenisation was less complete, with traces of hyphae remaining. Terrestrial animal fossils have not been found at the locality, but scorpions, pseudoscorpions, Opiliones, mites, centipedes (carnivores) and millipedes, and Collembola (detritivores) have been recorded from the slightly younger Rhynie cherts. Studies of fungivory in extant arthropods have concentrated on Collembola and, to a lesser extent, mites, but their faecal pellets are much smaller than the fossil examples. Millipedes, based on body size and faeces of extant forms, are considered more realistic producers, but little is known about fungal feeding in these animals. Regardless of the affinities of the producers, the diversity in morphology, sizes, aggregations, and composition of nematophyte-containing examples suggests that fungivory was an important component of carbon cycling in early terrestrial ecosystems.
\end{abstract}

Keywords Coprolites $\cdot$ Fungivory $\cdot$ Nematophytes $\cdot$ Devonian $\cdot$ Nutrient cycling $\cdot$ Early ecosystems

\section{Introduction}

As a consequence of the dearth of animal fossils, investigations of the colonisation of the land have traditionally been dominated by studies on the nature and affinities of the first

Handling Editor: Mike Reich.

Dianne Edwards

EdwardsD2@cardiff.ac.uk

$\triangle$ Jennifer L. Morris

drjenlmorris@gmail.com

1 School of Earth and Ocean Sciences, Cardiff University, Main Building, Park Place, Cardiff CF10 3AT, UK

2 School of Biosciences, Cardiff University, Sir Martin Evans Building, Museum Avenue, Cardiff CF10 3AX, UK

3 Department of Geology, University of Kansas, Lawrence, KS 66045, USA

4 Natural History Museum, London SW7 5BD, UK vascular plants (tracheophytes). These possessed the anatomical and biochemical adaptations allowing survival in a drying environment. More recently, attention has focussed on dispersed spores (cryptospores) in Ordovician strata (Rubinstein et al. 2010), where body fossils are lacking, but the parent plants are thought to be stem group embryophytes with bryophytes as their nearest living relatives.

Rocks of the Welsh Borderland have proved a veritable treasure trove for the history of early land vegetation as they present an almost continuous sequence of strata from Ordovician through Lower Devonian times that are conducive to the preservation of spores and megafossils (Edwards and Richardson 2004). Particularly noteworthy is a stream-side locality in the Lochkovian (Lower Devonian) which has yielded a diverse flora preserved as charcoal (Morris et al. 2018), thus revealing far greater anatomical detail than is seen in coeval coalified compression fossils. This Lagerstätte has also produced non-plant fossils that allow insights into an early terrestrial ecosystem including plants, fungi and, 
indirectly, evidence of plant and fungal/animal interactions (Edwards et al. 1995, 2012). The source strata are slightly older than the much better known Scottish Pragian Rhynie chert ecosystem, which is preserved in phenomenal detail by the siliceous waters of hot springs. The chert contains plants growing in situ, terrestrial animals such as arachnids, springtails, myriapods and nematodes, pools containing crustaceans and abundant fungi, both aquatic and those colonising both dead and living plants (Edwards et al. 2017 and papers therein). Such fungi have transformed our understanding of their early diversity and ecological roles (Taylor et al. 2015; Krings et al. 2017). Perhaps, the most surprising recent discovery is the identification of Prototaxites, an organism composed of diverse branching tubes in axes ranging from a few millimetres to $8 \mathrm{~m}$ in length and $1 \mathrm{~m}$ in diameter, as a basal ascomycete based on inoperculate, polysporous asci lacking croziers (Honegger et al. 2017). The affinities of Prototaxites had long been debated, but had been considered a basidiomycete on hyphal characteristics (Hueber 2001). A previous interpretation by Lang (1937) had placed it in his new 'class', the Nematophytales, together with another enigmatic organism, Nematothallus. The latter, widespread in Late Silurian and Early Devonian terrestrial biotas, is now known as a stratified thalloid organism with superficial, usually uniseriate, cortex overlying a palisade zone of parallel tubes and basal wefts of narrow hyphae (Edwards et al. 2013). It was compared with certain presentday lichens; however, specimens usually lack evidence of photobionts. These were identified only in two charcoalified thalli from the same locality, thus permitting assignation to cyanobacterial and algal lichens (Honegger et al. 2013). Such investigations based on this Lochkovian locality have not only demonstrated the existence of fungi in a terrestrial ecosystem, but, in their coverage of bedding planes here and also in coeval localities in the Welsh Borderland, they were an important component of a vegetation (Strother 2010) that consisted of tiny early land plants, a diverse ground cover, and a few towering giants such as Prototaxites.

Little is known to date about the roles animals played in the early terrestrial ecosystems of the Welsh Borderland, due primarily to the fact that body fossils are absent. However, indirect evidence of animal activities in these palaeoenvironments comes from coprolites. Previous studies had indicated that plant-animal interactions were based on coprolites dominated by embryophyte spores with lesser amounts of comminuted plants, but more recently nematophyte-dominated coprolites provided evidence of animal interaction with fungi (Edwards et al. 2012). Describing silicified specimens in the Rhynie chert, Habgood et al. (2004) had formalised taxonomic/nomenclatural aspects of coprolite studies by the erection of ichnogenera, Bacillafaex, Lancifaex, and Rotundafaex, based on morphology and contents. Here, we will adopt their scheme and add further examples, the commonest being a new type of coprolite consistently attached to mats of fungal hyphae.

\section{Geological setting, materials and methods}

The fossils were found within a grey siltstone horizon exposed in a stream section on the north side of Brown Clee Hill, Shropshire, UK (Edwards et al. 1994; NBCH, figure 4.1 in Morris et al. 2018). The sequence is part of the Freshwater West Formation of the Lower Old Red Sandstone of the Anglo-Welsh Basin (Barclay et al. 2015). Palynological assemblages were assigned to the middle sub-zone of the micrornatus-newportensis Sporomorph Assemblage Biozone (Richardson and McGregor 1986), indicating an early Lochkovian age. The fossils were extracted using $\mathrm{HCl}$ and HF to dissolve the siltstone matrix and then were recovered by coarse sieving. The fossil fragments were then sorted and initially examined under a stereo microscope, followed by scanning electron microscopy (FEI ESEM-FEG), as described previously (Morris et al. 2011).

\section{Descriptions}

1. Coprolites associated with hyphal mats Bacillafaex myceliorum isp. nov. (Figs. 1, 2, 3; see "Appendix").

Description. While sifting through coalified flakes of presumed nematophytes that dominate the acid digested $(\mathrm{HCl}$, HF) macerates recovered after coarse sieving, a few bearing small cylindrical structures were recovered. These were conspicuous under the dissecting microscope as glossy dark entities on a brown 'substrate' and were tentatively identified as coprolites. In all, about 50 were recovered on ten specimens, with numbers and their distribution on an individual fragment being variable and lacking any pattern (Fig. 1a-e), or in clusters (Fig. 1f). Some coprolites are more or less cylindrical with truncated (Fig. 2ai, bii) or slightly rounded extremities (Fig. 2aii, bi). Others show abrupt tapering from the cylindrical core either at one (Fig. 2c, di) or both ends (Fig. 2dii, e). Coprolite maximum width ranges between 125 and $185 \mu \mathrm{m}(x=175 \mu \mathrm{m}, n=50)$, but the length dimension depends on whether or not the ends are tapered. Maximum length averages $355 \mu \mathrm{m}$ (range 195-500 $\mu \mathrm{m} ; n=6$ ) where both ends tapered and $265 \mu \mathrm{m}$ (range 170-355 $\mu \mathrm{m}: n=18$ ) where only the body is measured. Intact surfaces are overall smooth with occasional dimpling or pin-point indentations (Fig. 2d, f). Irregularly fractured or stripped surfaces (Fig. 2g) and partially collapsed (Fig. 2h) examples reveal the contents, but these were best exposed in fractured transverse examples which are circular in outline and reveal a narrow, homogeneous layer surrounding an undifferentiated 

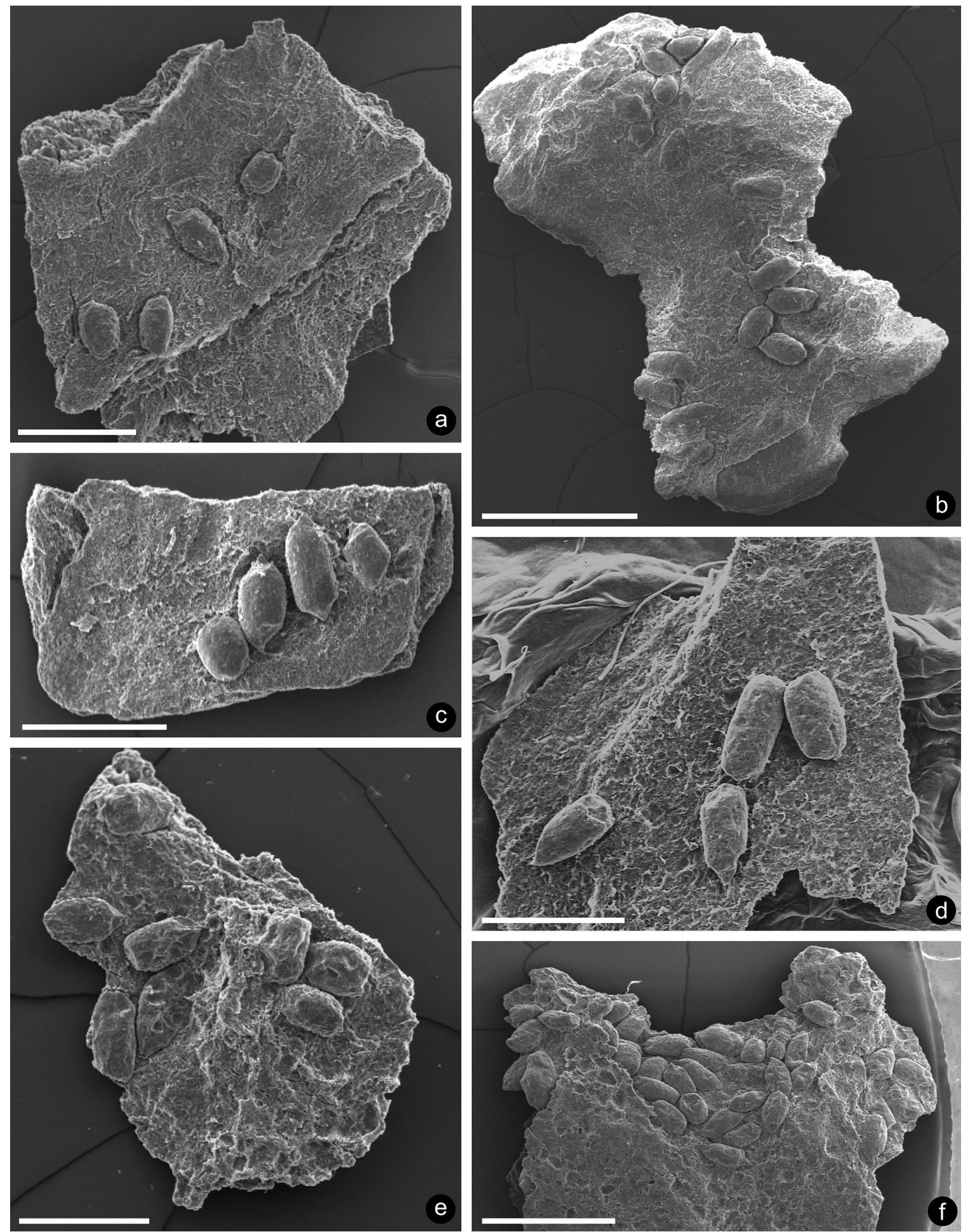

Fig. 1 Coprolites associated with hyphal mats, Bacillafaex myceliorum isp. nov.: a NMW 2019.17G.1; b NMW 2019.17G.2; c NMW 2019.17G.3; d NMW 2019.17G.4; e NMW 2019.17G.5; f NMW 2019.17G.6; scale bars: a, c-e 500 m; b, f 1 mm 

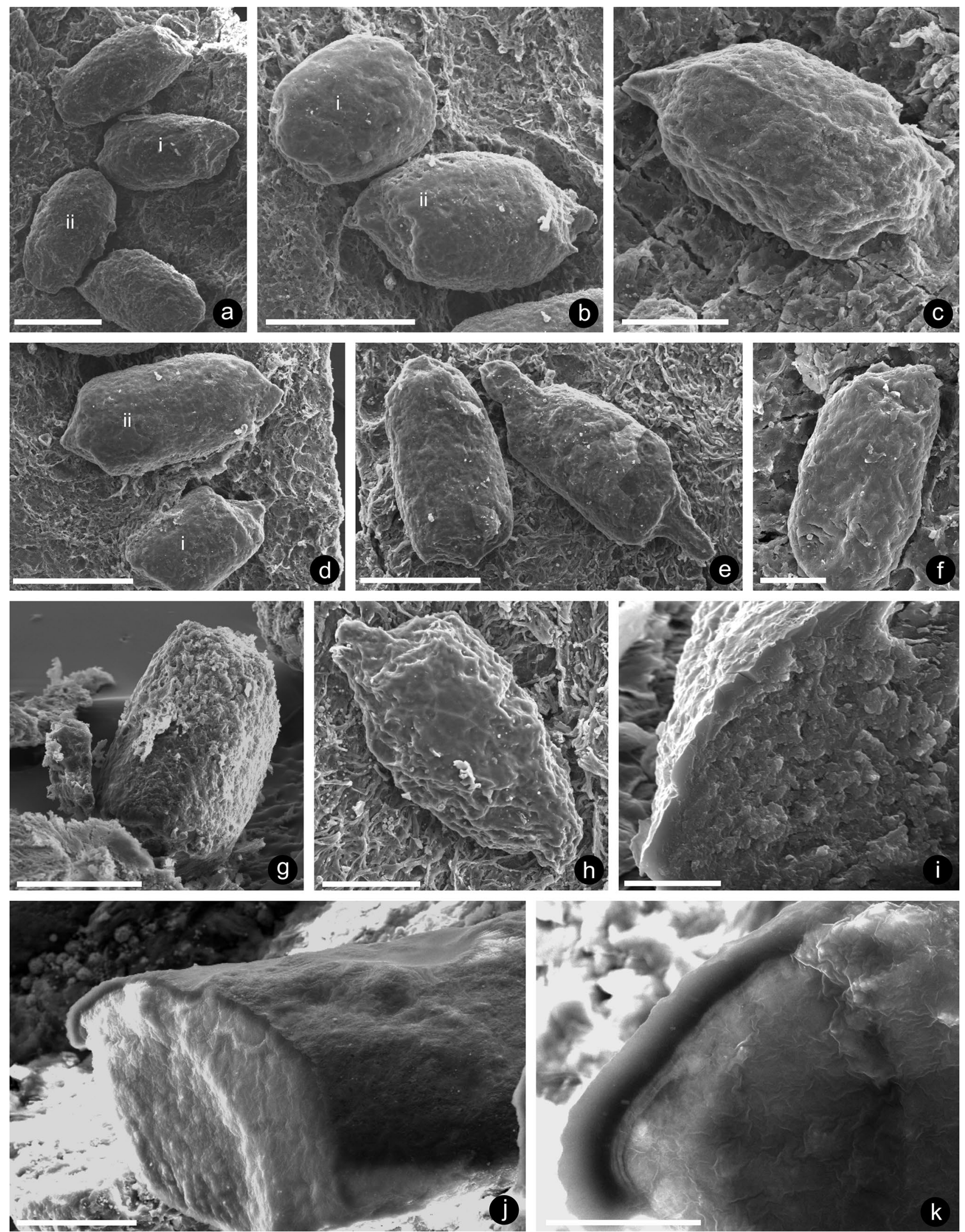
४Fig. 2 Shapes and surfaces of coprolites, Bacillafaex myceliorum, associated with hyphal mats: a with truncated extremities (i), and with rounded extremities (ii); $\mathbf{b}$ with rounded extremities (i) and fractured at one end (ii); $\mathbf{c}$ tapered at one end; $\mathbf{d}$ tapered at one end (i) and tapered at both ends (ii); e tapered at both ends; $\mathbf{f}$ smooth surface with occasional dimpling; g stripped off surface, revealing contents; h partially collapsed coprolite, revealing contents; i fracture revealing homogeneous outer layer and contents with uniform fused granular texture; $\mathbf{j}$, k coprolite split with a razor blade, revealing smooth, well-defined and homogeneous limiting layer; specimens: a, i NMW 2019.17G.2; b, d, g NMW 2019.17G.3; c, j, k NMW 2019.17G.6; e NMW 2019.17G.7; f NMW 2019.17G.8; h NMW 2019.17G.1; scale bars: a, b-e $200 \mu \mathrm{m} ; \mathbf{c}, \mathbf{g}, \mathbf{h} 100 \mu \mathrm{m} ; \mathbf{f}, \mathbf{j} 50 \mu \mathrm{m} ; \mathbf{i}, \mathbf{k} 20 \mu \mathrm{m}$

region with a uniform fused granular texture (Fig. 2i). The section illustrated in Fig. $2 \mathrm{j}$ was produced by splitting a coprolite with a razor blade producing a flatter, smoother, homogenised surface and, unlike in fractured examples, a well-defined limiting layer 5-7 $\mu \mathrm{m}$ wide (Fig. $2 \mathrm{k}$ ) with further layering adjacent to the contents.

The substrates below the coprolites are also variable in appearance, the best preserved composed entirely of mats of interweaving hyphae (Fig. 3a-c). Individual hyphae are rarely well preserved and vary in diameter between 1.8 and $14.5 \mu \mathrm{m}(x=4.3 \mu \mathrm{m}, n=57)$. They probably branched, but compaction and fusion of overlying examples make distinction difficult. Their hollow nature (Fig. 3b) is particularly evident where each is filled with a row of pyrite microcrystals. Other hyphae show degrees of fusion and degradation (Fig. 3d), while a few examples are almost completely fused producing a smoother (Fig. 3e) surface. The latter may be pock-marked (Fig. 3f) with often smooth centres of depressions (Fig. 3g, h). Darker areas remain where coprolites have become dislodged. While the flakes were picked out of macerates as potential nematophytes, those supporting coprolites do not show the typical tripartite organisation described for the Nematothallus complex (Edwards et al. 2013, 2018), but are closest to the basal layer of interweaving hyphae and to clusters of hyphae recovered on maceration. The variation in length of hyphae suggests that the tissue may already have been partially degraded naturally, or broken up by grazing before consumption by the coprolite producers, as is the damage seen on individual hyphae. Bacteria have not been preserved on any specimens.

Comparisons. In shape, amorphous content, and association with mats of hyphae, these coprolites are distinct from those already described from the locality (Edwards et al. $1995,2012)$. An exception containing homogenised granular material was illustrated by Habgood (2000: pl. 66.5). Of the three taxa erected by Habgood et al. (2004) from the Rhynie chert, Rotundafaex can be eliminated on gross morphology, and Lancifaex, because its diagnosis states that its contents were never exclusively amorphous. Closest is Bacillafaex, which was diagnosed as rod-shaped, with parallel longitudinal margins, blunt or rounded poles, and amorphous contents. B. constipata (200-400 $\mu \mathrm{m}$ long, $<100 \mu \mathrm{m}$ wide) had rounded ends and occurred in the chert in clusters of up to 30 individuals. By contrast, $B$. mina is much shorter $(<100 \mu \mathrm{m}$ long $)$ and occurred in small groups $(<4)$ in sporangia. These new examples conform on content, body shape and size to $B$. constipata, but show tapering at the poles and, as such, merit a new ichnospecies, B. myceliorum, the specific epithet reflecting the associated tissues (see "Appendix" for systematic ichnotaxonomy).

The coprolite producer. The contents of the coprolites give limited evidence for the diet of the consumer. Given the absence of relevant anatomical data, it is unlikely to have consumed living or dead plant biomass, but the consistent position of the coprolites on a nematophyte point to fungivory. Size eliminates very small arthropods such as Collembola and mites, although today they are known to consume fungi (e.g., A'Bear et al. 2010; Crowther et al. 2011). Considering millipedes (including the extinct arthropleurids), based on morphology and shape in section (Bullock et al. 1985), the coprolites would fall into the tailed conoids and pointed tailed conoid categories of faeces produced by Julidae and Glomeridae. In making such comparisons, we are mindful of the dangers of concluding that extinct members of clades were of similar size to extant representatives (cf. size of Carboniferous arthropleurids) and that size can be influenced by environmental factors such as temperature (e.g., tropical v. temperate ecosystems). However, coeval arthropods [e.g., in the slightly younger Rhynie chert (Dunlop and Garwood 2017)] were of similar size and lived at similar, although admittedly subtropical, latitudes.

\section{Specimen NMW 2019.17G.9 (Fig. 4).}

Description. The entire specimen $(3.9 \times 2.1 \mathrm{~mm})$ comprises a roughly elliptical hyphal fragment ('substrate') bearing an elongate pile of cylindrical coprolites $(2.5 \times 0.8 \mathrm{~mm})$ which is rounded at one end and truncated at the other (Fig. 4a), the latter coincident with the fractured end of the 'substrate'. The pile is at least three coprolites deep towards the centre and appears to extend into the substrate. This superpositioning of coprolites limits visibility for measurement. Each coprolite is cylindrical with rounded ends, the four fully exposed examples measuring $375 \times 110,375 \times 97,429 \times 115$, and $350 \times 115 \mu \mathrm{m}$. Surfaces are relatively smooth but discontinuous (Fig. 4b) and damaged examples show an irregular reticulum below (Fig. 4c). That in Fig. 4d is transversely fractured and shows an occasional banded tube (arrowed).

The 'substrate' comprises mainly parallel-sided hyphae separated by less well-preserved material (Fig. 4e). Most are compressed (8.2-20.0 $\mu \mathrm{m}$ diameter, $x=12.4 \mu \mathrm{m})$, but a few fractured examples are circular in cross section 

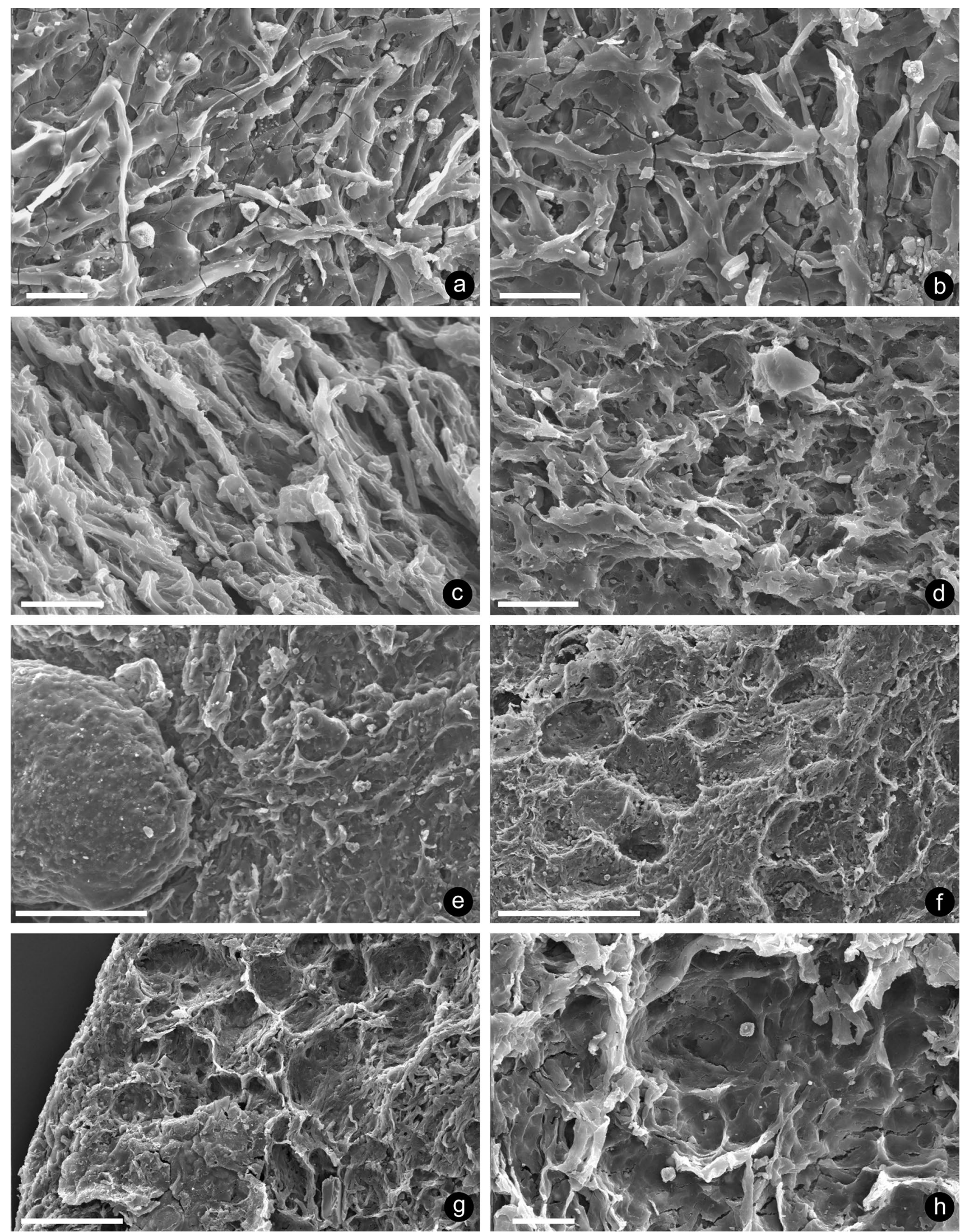
4Fig. 3 Underlying matrices of hyphal mats associated with Bacillafaex myceliorum: a-c interweaving hyphae; $\mathbf{d}$ hyphae with a degree of fusion and degradation; e hyphae completely fused producing a smoother surface; $\mathbf{f}$ smooth surface with pock marks; $\mathbf{g}-\mathbf{h}$ pockmarked surface, with smooth centres of depressions, where coprolites have been dislodged; specimens: a, b NMW 2019.17G.1; c, e NMW 2019.17G.2; d NMW 2019.17G.3; f, g, h NMW 2019.17G.8; scale bars: a-d, h $20 \mu \mathrm{m} ; \mathbf{e}, \mathbf{g} 100 \mu \mathrm{m} ; \mathbf{f} 200 \mu \mathrm{m}$

(Fig. 4f). A broken off fragment (Fig. 4g) shows that the intact outer surface of the fragment was smooth (Fig. 4h) and limited by a layer of cells (Fig. 4h, i), interpreted as the cortical layer in an intact thalloid Nematothallus complex (Edwards et al. 2013) where it covers a palisade zone of hyphae, similar to the poorly preserved hyphal zone described above. This suggests that the coprolites were deposited on the underside of a continuous thallus. Further examination showed adherence to a layer of broken down palisade tissue arrowed in Fig. 4j, magnified in Fig. 4k. More or less spherical structures in this region resemble medullary spots, which are concentrations of small hyphae and are characteristic of Prototaxites (arrowed in Fig. 41).

Comparisons. The positioning of the coprolites on a fragment of Nematothallus is highly suggestive of nematophyte consumption. Contents of individual examples vary (Fig. 4c compared with Fig. 4d) but where 'best preserved' (Fig. 4d) contain banded tubes within areas where homogenised walls enclose irregularly shaped voids. These contents match the type 2 forms described by Edwards et al. (2012) present in the chains of coprolites assigned to Lancifaex nematophyta as well as in isolated examples, and would be placed in the same ichnotaxon apart from their clustering and relationship with a Nematothallus-type thallus. However, because we have just one example of the cluster and its associated mats, we are reluctant to name it at this time.

The coprolite producer. The contents of the coprolites eliminate the likelihood that the consumer ate plant material, either living, dead or as spores. The position of the coprolites on a Nematothallus thallus points to a fungivore. The existence of very fragmentary nematophyte tissues immediately below the mound of coprolites suggests mastication/chopping up of the tissues before ingestion, although individual hyphal elements cannot be detected in the coprolites. A millipede is a likely candidate based on size of the coprolites, as was discussed in earlier papers on the locality, extant forms, and Rhynie chert examples (Habgood 2000; Habgood et al. 2004).

\section{Specimen NMW 2019.17G.10 (Fig. 5).}

Description. The specimen, a more or less cylindrical body (Fig. 5a) giving an impression of slight twisting, is circular in cross section (Fig. 5b) and tapers at both poles. Its overall length is $1.4 \mathrm{~mm}$ and diameter is $0.56 \mathrm{~mm}$. The surface, where intact, is irregular and smooth in places, but in areas sloughed off reveals fragments of Nematothallus 'cuticle' (Fig. 5c), banded tubes (Fig. 5d), and less readily identifiable regions (Fig. 5e). Similar structures were observed after transverse fracture (Fig. 5f, g), but here, some of the tubes possessed internal ornament/thickenings reminiscent of early embryophytes of uncertain affinity (Fig. $5 \mathrm{~g}-\mathrm{j}$ ) (Edwards et al. 2013), but most of the content, comprising voids and thickened walls, is unidentifiable. Figure $5 \mathrm{k}$ shows a tube with mineral infill (probably oxidised pyrite) and also the homogeneous limiting zone, which does not form as well-defined layer as seen in the B. myceliorum.

Comparisons. The coprolite differs from others described here in size and contents. Considering the morphological silhouettes of coprolites from the Rhynie chert illustrated by Habgood et al. (2004), it is closest to the tapered asymmetrical form, but there is no match in terms of content in their Lancifaex group. Of the non-segmented coprolites containing remains of nematophytes described by Edwards et al. (2012), it is closest in shape and to a lesser extent size $(935 \times 255 \mu \mathrm{m})$ to that illustrated in their fig. $9 \mathrm{k}$, although a continuous peripheral layer is here more prominent and the contents more homogenised. In content, it compares favourably with some of the segmented forms, which contained banded tubes, Nematothallus group 'cuticles', and non-cellular material with homogenised walls, although the diversity in internal ornament seen here was not present. Further specimens are needed to allow circumscription of a new taxon.

The coprolite producer. The presence of diverse tissues of nematophytes now interpreted as possessing fungal affinities (e.g., Edwards et al. 2013; Honegger et al. 2017) indicates a fungivore and from the size of the coprolite probably a millipede (including arthropleurid). The demonstration of tubes with thickenings closer to those of basal embryophytes than banded tubes (Fig. 5g-j) (Edwards et al. 2003) raises the possibility of a more diverse diet, but further data are required to substantiate this.

\section{Specimen NMW 2019.17G.11 (Fig. 6).}

Description. The specimen comprises an isolated cluster of more than 20 coprolites (Fig. 6a). Initial observations showed no extraneous material, but when the fragment was turned over (Fig. 6b), a small smooth amorphous area is seen between them which possibly represents the remains of a substrate (Fig. 6b). Measurements of individual coprolites lack accuracy because of overlapping and tilting: a fusiform example is $284 \mu \mathrm{m}$ long and $84 \mu \mathrm{m}$ wide (Fig. 6c) and a truncated cylindrical one, $195 \mu \mathrm{m}$ long and $108 \mu \mathrm{m}$ wide 

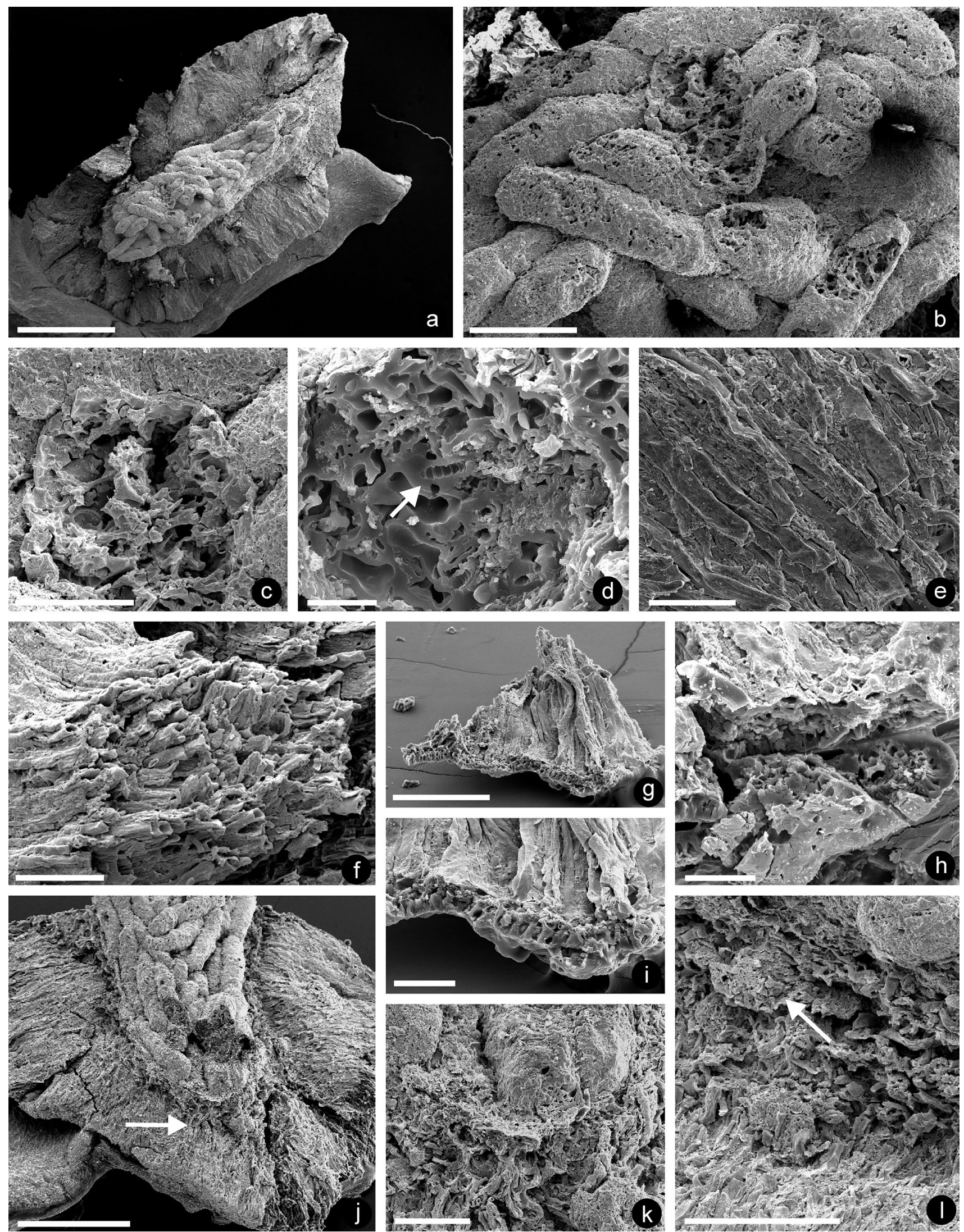
४Fig. 4 Specimen NMW 2019.17G.9: a hyphal fragment bearing a pile of coprolites; b magnification of cylindrical coprolites with rounded ends, showing relatively smooth but discontinuous surfaces; c damaged coprolite, showing irregular reticulum; d transverse fracture showing contents, including the occasional banded tube (arrow); e magnification of the hyphal 'substrate', comprising parallel-sided hyphae; f, partially fractured hyphal 'substrate', with circular hyphae in cross section; g, isolated fragment of specimen demonstrating Nematothallus organisation; $\mathbf{h}$ folded area with smooth outer surface and poorly preserved limiting layer of cells; $\mathbf{i}$ magnification of part of $\mathbf{g}$ showing cortex and palisade hyphae; $\mathbf{j}$ oblique view of fragment, arrow indicates zone of fragmented narrow hyphae; $\mathbf{k}$ magnification of zone in $\mathbf{j}$; $\mathbf{l}$ almost spherical structures of concentrations of small hyphae in fragmented zone resembling medullary spots, arrowed; scale bars: a $1 \mathrm{~mm} ; \mathbf{b}, \mathbf{g}, \mathbf{l} 200 \mu \mathrm{m} ; \mathbf{c}, \mathbf{f}, \mathbf{k} 100 \mu \mathrm{m} ; \mathbf{d} 20 \mu \mathrm{m} ; \mathbf{e}, \mathbf{h}, \mathbf{i}$ $50 \mu \mathrm{m} ; \mathbf{j} 500 \mu \mathrm{m}$

(Fig. 6d). Surfaces of both are similar, essentially smooth, but with irregularly distributed, pin-point depressions. Transversely fractured examples reveal irregular granules separated by more or less uniformly sized cavities and fused at the margin (Fig. 6e), but no indication of tissues.

Comparisons. Of all the charcoalified coprolites so far examined, these most closely resemble an isolated, very large, truncated example $(1.93 \times 0.84 \mathrm{~mm})$ described by Edwards et al. (2012) with superficial oblique depressions (their fig. 9a) and intervening less regular grooves (their fig. 9c) whose content comprised closely packed fused granules (their fig. 9d). Their range in morphology is encompassed by the Lancifaex simplex Group A (i) of Habgood et al. (2004: their fig. 7). Their content would be closest to those illustrated with predominantly amorphous composition, although detailed comparison of sections preserved in chert with the three-dimensional preservation in charcoal is impossible.

The coprolite producer. The coprolites' contents offer no clues as to the original diet of the consumer. Higher plants seem unlikely in the absence of any indication of anticipated resilient tissues or spores.

\section{Specimen NMW 2019.17G.12 (Fig. 7).}

Description. This cylindrical specimen with tapering poles (Fig. 7a) has a wrinkled surface somewhat similar to shrivelled stems of embryophytes. A rounded pole appears intact with continuous covering (Fig. 7b, c), but the other is fractured revealing an irregular network of homogeneous walls (Fig. 7d, e). When transversely fractured at the midpoint, the circular cross section (Fig. 7f) revealed abundant microcrystalline pyrite occupying the voids in an irregular reticulum of homogenised walls. Treatment with Schultze's solution removed the pyrite (Fig. $7 \mathrm{~g}$ ) and although revealing the three-dimensional 'skeleton' of coalified material, individual cells or hyphae could not be detected, except for the fragments of walls of fungal hyphae with internal thickenings (banded tubes) (Fig. 7h, i). 'Walls' tended to be thicker towards the periphery (Fig. $7 \mathrm{j}, \mathrm{k}$ ), whilst some areas of enclosed tissue were more variable than others (c. Fig. 7j, 1).

Comparisons. Based on overall shape, surface characters, and disorganised contents, the specimen is identified as a coprolite, but in the combination of characters is unlike others yet described in charcoalified examples. In terms of content, it is closest but not identical to isolated examples with fragmentary nematophytes (Edwards et al. 2012) and in morphology would fall into the L. simplex complex Group A of Habgood et al. (2004), but nematophyte remains have never been recorded in the silicified examples, although they do contain traces of fungal hyphae.

The coprolite producer. Although contents are poorly preserved, a fungal nutrient source seems more likely than that derived from embryophytes (Edwards et al. 1995), and based on overall shape and size as present in extant forms, the consumer was probably a millipede.

\section{General discussion}

\section{Comparisons with other Lower Devonian coprolites}

The first comprehensive treatment of Lower Devonian coprolites in an ichnotaxonomical framework, based on silicified examples from the Rhynie chert, was by Habgood et al. (2004). They created three ichnogenera, Bacillafaex, Lancifaex, and Rotundafaex, distinguished on morphology, size, content, and distribution. Of the three, the last can be eliminated on gross morphology, while the other two are relevant to this study, viz., Bacillafaex, for rod-shaped coprolites with amorphous content and Lancifaex, for elongate corpolites with particulate content, including plant and fungal spores, hyphae, degraded cuticle, together with amorphous organic material. The specimens associated with the hyphal mats are similar to the former, but with no exact Rhynie chert equivalent. While the majority of specimens would conform to Bacillafaex on the basis of content, the extensions to the cylindrical central bodies in the charcoalified specimens are absent in Bacillafaex. They are present in some examples of L. simplex (see fig. 7 in Habgood et al. 2004). None of the Rhynie chert examples of the Lancifaex ichnospecies are dominated by fungal/nematophyte remains. By contrast, Edwards et al. (2012) assigned coprolites filled with nematophytes to L. nematophyta which differed from Habgood et al.'s ichnospecies in that each specimen was divided into chains of two-to-six discrete discoidal structures. In addition, they described, but did not name, isolated examples 

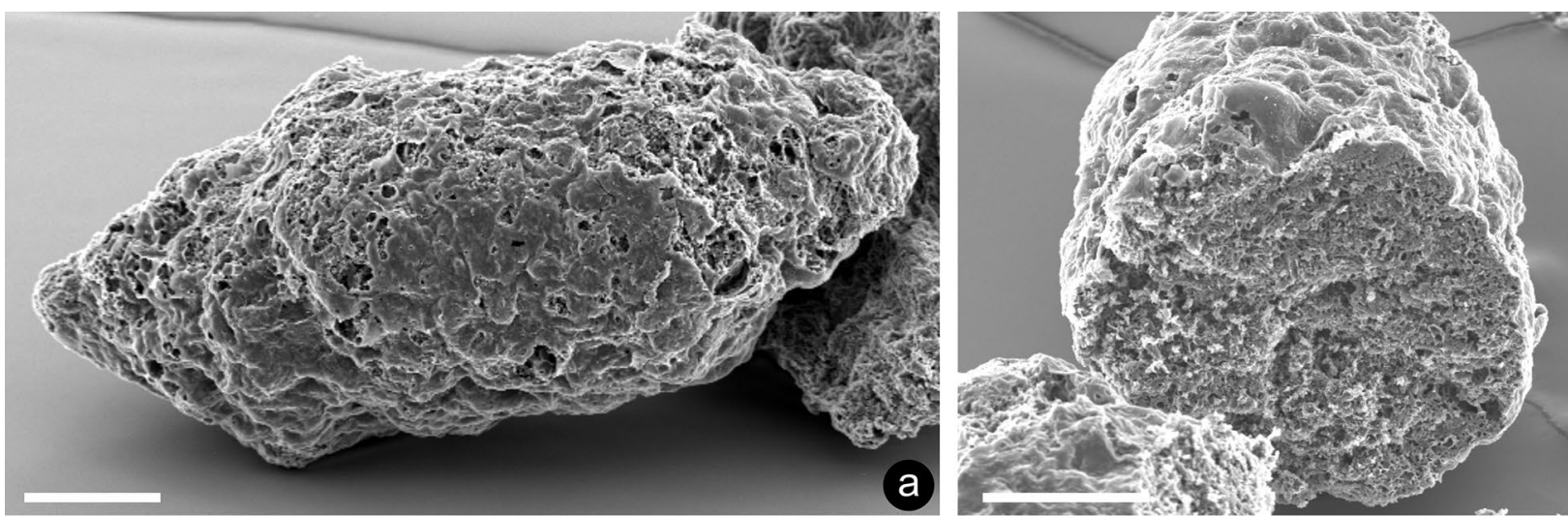

b
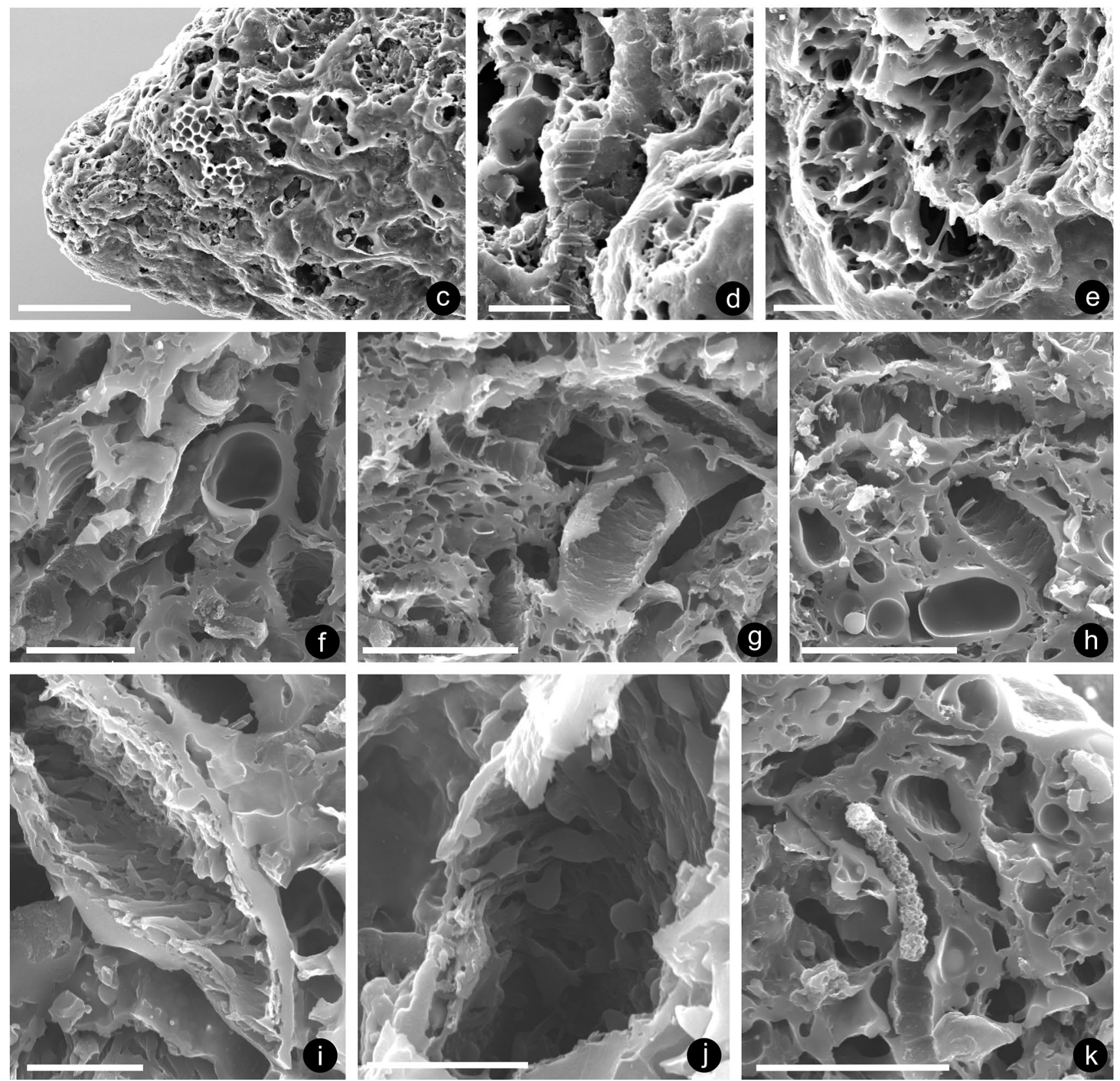
४Fig. 5 Specimen NMW 2019.17G.10; a coprolite with an elongate cylindrical body, and impression of slight twisting, tapering at both poles; $\mathbf{b}$ transverse fracture; $\mathbf{c}$ magnification of one pole, where smooth surface has sloughed off, revealing fragments of Nematothallus cuticle; exposed subsurface with two banded tubes (d) and unidentifiable reticulate structures (e); fractured surface transverse section, exposing banded tube (f); and some tubular fragments that possess internal ornament reminiscent of the axial anatomy of early embryophytes $(\mathbf{g}-\mathbf{j})$; $\mathbf{k}$ section through the coprolite showing infilled banded tube; scale bars: a, b $200 \mu \mathrm{m}$; c $100 \mu \mathrm{m} ; \mathbf{d}$, e, g, h, k $20 \mu \mathrm{m}$; f $10 \mu \mathrm{m} ; \mathbf{i}, \mathbf{j} 5 \mu \mathrm{m}$

with one cylindrical example containing smooth hyphae and banded tubes (their figs. $9 \mathrm{~h}-\mathrm{j}$ ), a second with more diverse nematophyte remains (their figs. 10d-f), and a further example of similar shape but slightly longer and filled with compacted granular material (their figs. 9a, d).

Habgood (2000) illustrated a number of isolated charcoalified examples from the same locality as those described here. They show diversity in content, but the majority contain spores, or spores with comminuted plant material. However, she illustrated one example containing homogenised granular material similar to the majority described here, another exclusively of narrow, smooth, very well-preserved hyphae (her pls. 66.5, 66.6), another with areas of banded tubes (her pls. 66.3, 66.4) and a cylindrical example with tapering extension at one end (her pl. 72.1-4) that contained comminuted nematophytes.

With two exceptions, the new coprolites described here were unequivocally produced by animals consuming nematophytes, now considered fungi (Edwards et al. 2013, 2018) and, in one of the exceptions where contents are homogenised, they are consistently associated with mats of hyphae. The variation in appearance of contents reflects the extent to which tissues can be recognised and hence the degree of degradation during the feeding process. The extent of homogenisation is particularly interesting. Could it result when tissues that are not easily digested were compacted during progress through the gut? Could amorphous areas indicate more complete digestion of the fungal cell walls? Is this how the completely homogenised contents of B. myceliorum were produced? Such questions lead to the more general one on the digestibility of chitinous/cellulose cell walls, the possible evolution of chitinases in certain early terrestrial arthropods and the role(s) of gut microorganisms in the process.

On the assumption that the consumers were millipedes, the majority today live on decaying plant material, but cannot digest cell walls in either living or decaying tissue, as shown experimentally in Cardiff (Habgood 2000). These arthropods masticate substrate before ingestion, and then extract the soluble nutrients from the damaged tissues after ingestion, followed by excretion of the undigested energy source. There is no evidence of breakdown of walls either in ground tissues or spores. The coprolites described here that contain nematophyte remains in 'pristine condition' would fit into this feeding scenario and hint that the substrate was probably living or recently dead. The case of the amorphous contents leads to the question as to whether already decaying material before ingestion could have resulted in greater homogenisation.

The unique specimen (NMW 2019.17G.9; Fig. 4) shows a cluster of coprolites associated with a relatively poorly preserved piece of a Nematothallus thallus and surrounded by fragments of palisade hyphae. The coprolites contain an irregular network of presumed decaying hyphae but no homogenised areas. Banded tubes are present, which are known to occur in certain prototaxalian taxa (e.g., Nematasketum, Burgess and Edwards 1988). However, it has also been suggested that the presence of banded tubes might represent saprotrophic activity on decaying material, as illustrated on a Tortilicaulis specimen (NMW 96.5G.9), where banded tubes are attached to the cuticle of the sporangial wall (Edwards et al. 1996). This example here points to feeding on decaying substrates, but more experiments are needed on extant fungivores to elucidate details of feeding, including the nature of the energy source. Rough observations concentrating on living fungi indicate that taxa feed on different regions of the mycelium, e.g., Collembola tend to feed on individual hyphae, while millipedes are less selective, grazing in arcs on different hyphal sizes, at different distances from the growing tips.

\section{The consumers}

The above deliberations and previous discoveries (e.g., Edwards et al. 2012) point to the existence of fungivores in this early terrestrial ecosystem, while the variation in content and morphology point to a number of types of consumer. Further discussion is limited by the almost complete absence of fossil evidence for arthropods at the locality, although these occur in more or less coeval rocks elsewhere and in particular the Rhynie cherts (for latter see recent review by Dunlop and Garwood 2017). Most Lower Devonian records are of carnivores (scorpions, pseudoscorpions, trigonotarbids, Opiliones, and centipedes). Nematodes provide evidence of parasitism in higher plants (Poinar et al. 2008), whilst detritivores include mites, millipedes (including arthropleurids) (Shear and Edgecombe 2010), and Collembola (e.g., Labandeira et al. 1988). From size and shape of both plant/spore and fungal examples, we conclude that millipedes were the coprolite producers, although details of consumption of fungi by extant millipedes and their impacts on soil ecosystems are rare (e.g. Crowther et al. 2011). Other extant fungivorous arthropods include Collembola (e.g., Boddy lab in Cardiff) and mites (Schneider et al. 2005). Collembola have been particularly well studied, but it should be 

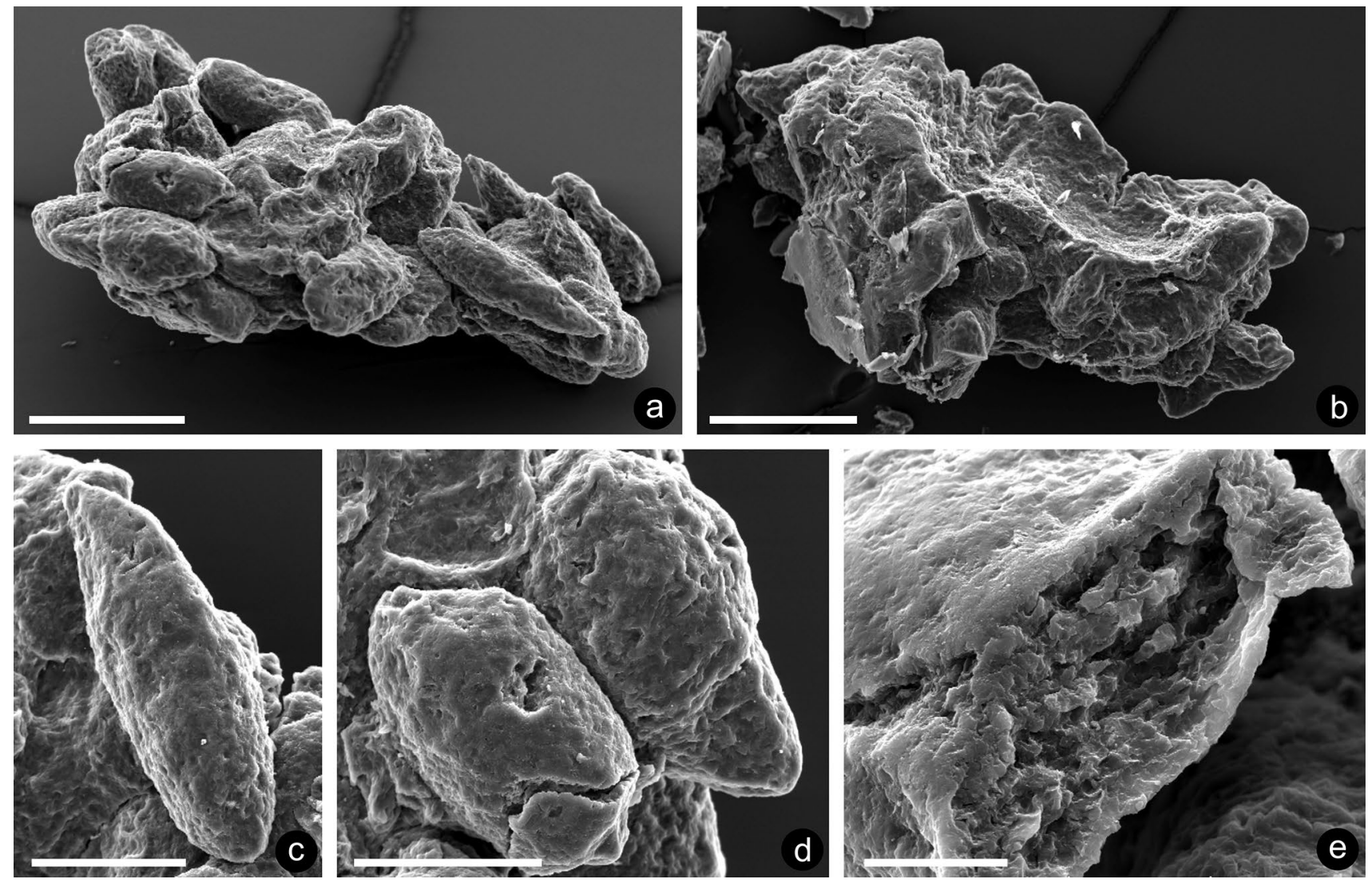

Fig. 6 Specimen NMW 2019.17G.11: a cluster of more than 20 coprolites; $\mathbf{b}$ reverse of specimen, showing smooth amorphous area which may represent the remains of a substrate; $\mathbf{c}$ fusiform coprolite; $\mathbf{d}$ trun- cated cylindrical coprolite; e transversely fractured coprolite revealing content of irregular granules, which are fused at the margin; scale bars: a, b $200 \mu \mathrm{m} ; \mathbf{c}, \mathbf{d} 100 \mu \mathrm{m} ; \mathbf{e} 20 \mu \mathrm{m}$ noted that experiments (A'Bear et al. 2010; Crowther et al. 2011) have concentrated on the effects of grazing on basidiomycete mycelia and do not include investigations on the consumption of hyphae or analysis of the nature of faeces. However, in a different approach involving the distribution of enzymes, Berg et al. (2004) demonstrated that chitinases extracted from Collembola showed the capacity for digesting fungal cell walls. Studies on mites indicate consumption of lichens, mycorrhizal fungi (Schneider et al. 2005), and saprotrophic fungal hyphae (A'Bear et al. 2010). Of relevance here are the observations that in the lichenivorous oribatid mites Trhypochtonius tectorum and Trichoribatus trimaculatus, ovoid faecal pellets were enveloped in a slimy peritrophic membrane, a proteinaceous secretion which results in adhesion to the lichen substrate following excretion. We note that $B$. myceliorum is preserved attached to the webs of hyphae and also has a distinct peripheral layer, although in the lichen coprolites, details of the anatomy of the source are still apparent. Other similarities with mites
Fig. 7 Specimen NMW 2019.17G.12: a cylindrical coprolite with tapering poles and a wrinkled surface; $\mathbf{b}$, $\mathbf{c}$ part of intact pole one rounded pole; $\mathbf{d}$, e transversely fractured pole, revealing a network of homogeneous walls; $\mathbf{f}$ fractured transverse section at mid-point infilled with microcrystalline pyrite; $\mathbf{g}$ section $\mathbf{f}$ after treatment with Schultze's solution; $\mathbf{h}-\mathbf{l}$ variation in coprolite content; $\mathbf{h}, \mathbf{i}$ banded tubes; $\mathbf{j}$ limiting layer and granular content, the latter magnified in $\mathbf{I} ; \mathbf{k}$ transversely sectioned tubes; scale bars: a, f, g $200 \mu \mathrm{m} ; \mathbf{b}, \mathbf{d}, \mathbf{j} 50 \mu \mathrm{m}$; $\mathbf{c}, \mathbf{e}, \mathbf{h}, \mathbf{l} 20 \mu \mathrm{m} ; \mathbf{i} 10 \mu \mathrm{m} ; \mathbf{k} 5 \mu \mathrm{m}$

include clustering. Both Collembola and mites produce much smaller faeces than those described here.

Regardless of the identity of the consumers, here, we discuss the number of animals present in this early terrestrial ecosystem in which diversity in morphology and nature of content, based on coprolites, is suggestive of a number of selective feeders on fungi, in addition to those detritivores which inadvertently consumed fungal hyphae along with plant detritus. 

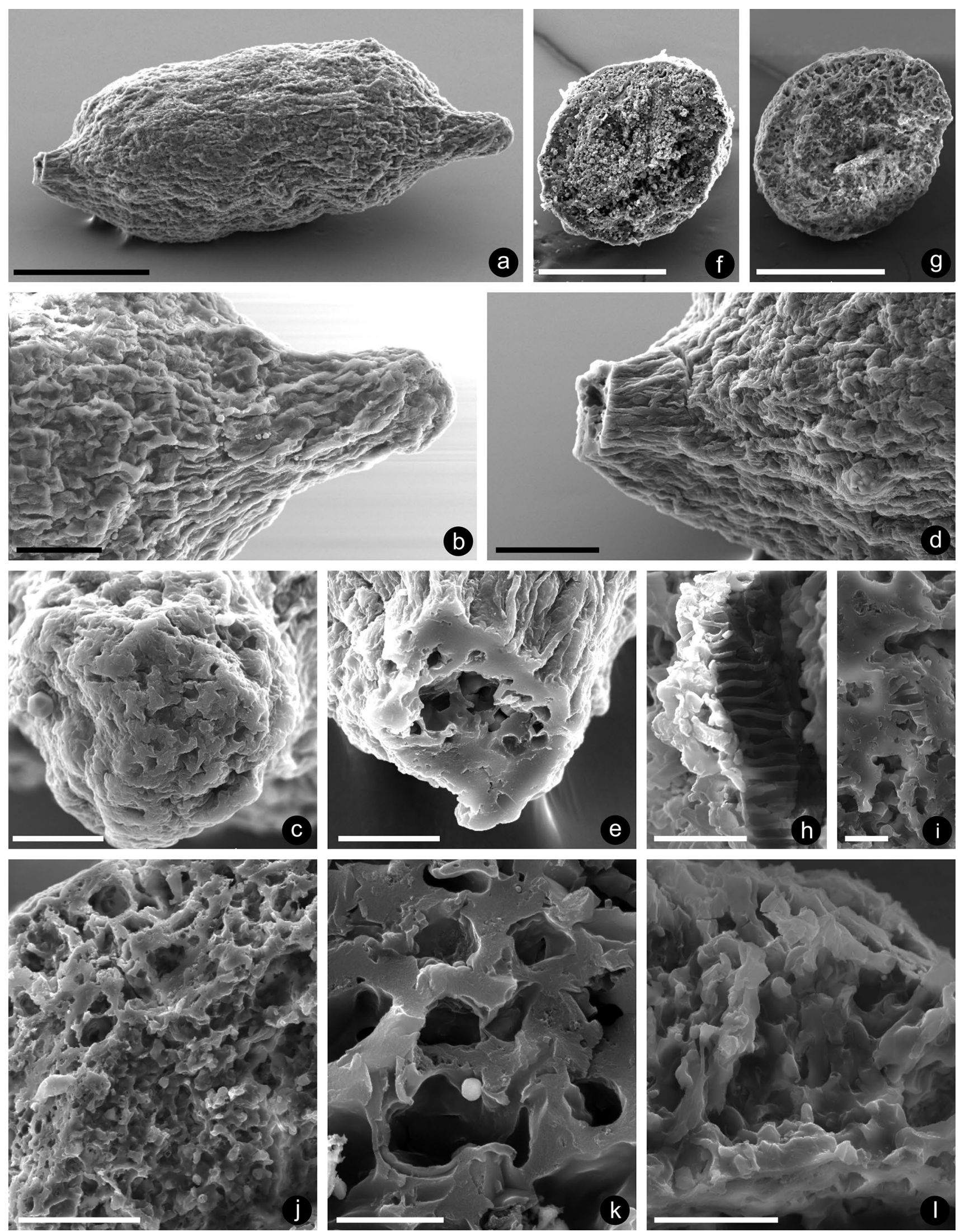
Feeders include those that produce:

1. coprolites in chains of predominantly discoidal entities containing remains of nematophytes (see Edwards et al. 2012: L. nematophyta);

2. isolated coprolites with nematophytes preserved to varying degrees (specimen NMW 2019.17G.10, Fig. 5 here; fig. 10b, e in Edwards et al. 2012). Morphological variation includes; (a) truncation (fig. 10d in Edwards et al. 2012), (b) twisting, (c) size (fig. 10a in Edwards et al. 2012);

3. coprolites associated with hyphal mats (B. myceliorum isp. nov., specimens NMW 2019.17G.1-8, Figs. 1, 2, 3);

4. coprolites associated with Nematothallus (specimen NMW 2019.17G.9, Fig. 4);

5. coprolites dominated by hyphae (fig. 9i in Edwards et al. 2012; pl. 66.5, 66.6 in Habgood 2000);

6. coprolites composed of banded forms (pl. 66.3, 66.4 in Habgood 2000);

7. isolated forms with extensions, ridged surfaces (specimen NMW 2019.17G.12, Fig. 7).

Excluded from the above are specimens with non-identifiable granular contents (e.g., NMW 2019.17G.11, Fig. 6).

Such a list indicates that there are potentially at least seven arthropods consuming only fungi in the ecosystem, but, given the limited numbers of each type and lack of information on variation in diet of the consumers, there remains the possibility that this is an overestimation of fungal feeders.

\section{Conclusions}

Coprolites are abundant in macerates at all stratigraphic levels at the locality. Most are fusiform, and scrutiny via a dissecting microscope allows identification of those containing spores. It has not been feasible to examine the hundreds of the remaining forms in the scanning electron microscope: some were picked at random and others selected because of unusual characteristics, such as surface features, organisation in chains, truncation, or extended poles. Thus, we have no idea of proportions of the various types and hence the frequency of the producers. However, Habgood (2000) attempted a more quantitative approach and screened over a hundred randomly picked coprolites. About $80 \%$ contained spores, which were the dominant component in many. Chains can now be assigned to L. nematophyta. Of those with amorphous content, three types were described, one with a tapering pole reminiscent of $B$. myceliorum. The majority although described as homogeneous, contained minutely fragmented to granular material with occasional banded tubes, hence probably contained digested nematophytes, but no traces of embryophytic tissues including spores. Thus, more than $10 \%$ of the coprolites were likely produced by fungivory, although with the proviso that in the case of completely homogeneous forms, we cannot exclude the possibility that embryophytes were being consumed. From these data, we can tentatively conclude that detritus produced by decaying plants was a more important nutrient source than fungi in this ecosystem, but confirmation would require more information on the size of populations of the animals concerned and the frequency of excretion. Nevertheless, the numbers also show that fungi were a not insignificant energy source in this Lochkovian ecosystem, perhaps not surprising given the frequency of the black coalified patches on bedding surfaces, which are interpreted as major fungal components of an early cryptogamic cover.

Acknowledgements This work was funded by Grants from The Leverhulme Trust and Gatsby Charitable Foundation, which are gratefully acknowledged.

Open Access This article is licensed under a Creative Commons Attribution 4.0 International License, which permits use, sharing, adaptation, distribution and reproduction in any medium or format, as long as you give appropriate credit to the original author(s) and the source, provide a link to the Creative Commons licence, and indicate if changes were made. The images or other third party material in this article are included in the article's Creative Commons licence, unless indicated otherwise in a credit line to the material. If material is not included in the article's Creative Commons licence and your intended use is not permitted by statutory regulation or exceeds the permitted use, you will need to obtain permission directly from the copyright holder. To view a copy of this licence, visit http://creativecommons.org/licenses/by/4.0/.

\section{Appendix}

\section{Systematic palaeontology}

Ichnogenus Bacillafaex Habgood, Hass and Kerp, 2004

Bacillafaex myceliorum Edwards, Axe, Morris, Boddy and Selden isp. nov.

Figures 1, 2 and 3

Derivation of name. After the consistent association of the coprolite with hyphae.

Holotype. NMW 2019.17G.6 (Figs. 1f, 2c, j, k).

Other material. NMW 2019.17G.1 (Figs. 1a, 2h, 3a-b); NMW 2019.17G.2 (Figs. 1b, 2a, i, 3c, e); NMW 2019.17G.3 (Figs. 1c, 2b, d, g, 3d); NMW 2019.17G.4 (Fig. 1d); NMW 2019.17G.5 (Fig. 1e); NMW 2019.17G.7 (Fig. 2e); NMW 2019.17G.8 (Figs. 2f, 3f-h). 
Repository. National Museum of Wales, Cardiff (NMW).

Locality and stratigraphy. Stream section on the north side of Brown Clee Hill, Shropshire, England. Lower part of the Freshwater West Formation (previously known as the Ditton Group), middle sub-zone of the micrornatus-newportensis Sporomorph Assemblage Biozone, Lochkovian (Lower Devonian).

Diagnosis. Individual coprolites are cylindrical with truncated, rounded, or abruptly tapering poles. Composed of amorphous/granular remains surrounded by a wall interpreted as a peritrophic membrane. Consistently adhering to mats of hyphae.

Description. Coprolites adhere to a flattened fragment of mycelium in which hyphae range from complete fusion to interweaving mats of entities ranging between 1.8 and $14.5 \mu \mathrm{m}$ in diameter. Body of individual coprolite is cylindrical with truncated, slightly rounded, or abrupt tapering at both or one end. On average, the central body is $265 \mu \mathrm{m}$ in length (170-355 $\mu \mathrm{m}, n=18)$ and $175 \mu \mathrm{m}$ wide (125$185 \mu \mathrm{m}, n=50)$; where both ends taper average coprolite length reaches $355 \mu \mathrm{m}(195-500 \mu \mathrm{m}, n=6)$. Intact surfaces are smooth with occasional dimpling or pitting. Fractured examples show a peritrophic, possibly layered, membrane, 5-7 $\mu \mathrm{m}$ wide, surrounding almost amorphous contents.

Occurrence. Known only from the type locality.

\section{References}

A'Bear, A.D., L. Boddy, G. Raspotnig, and T.H. Jones. 2010. Non trophic effects of oribatid mites on cord-forming basidiomycetes in soil microcosms. Ecological Entomology 35: 477-484. https:// doi.org/10.1111/j.1365-2311.2010.01204.x.

Barclay, W.J., J.R. Davies, R.D. Hillier, R.A. Waters. 2015. Lithostratigraphy of the Old Red Sandstone successions of the Anglo-Welsh Basin. British Geological Survey Research Report Rr/14/02, 1-196

Berg, M.P., M. Stoffer, and H.H. van der Heuvel. 2004. Feeding guilds in Collembola based on digestive enzymes. Pedobiologia 48: 589-601.

Burgess, N.D., and D. Edwards. 1988. A new Palaeozoic plant closely allied to Prototaxites Dawson. Botanical Journal of the Linnean Society 97: 189-203.

Bullock, P., N. Fedoroff, A. Jongerius, G. Stoops, and T. Tursina. 1985. Handbook for soil thin section description, 1-152. Wolverhampton: Waine Research Publications.

Crowther, T.W., L. Boddy, and T.H. Jones. 2011. Species-specific effects of soil fauna on fungal foraging and decomposition. Oecologia 167: 535-545. https://doi.org/10.1007/s00442-011-2005-1.

Dunlop, J.A., and R.J. Garwood. 2017. Terrestrial invertebrates in the Rhynie chert ecosystem. Philosophical Transactions of the Royal Society (B: Biological Sciences) 373: 20160493.
Edwards, D., and J.B. Richardson. 2004. Silurian and Lower Devonian plant assemblages from the Anglo-Welsh Basin: A palaeobotanical and palynological synthesis. Geological Journal 39: 375-402.

Edwards, D., U. Fanning, and J.B. Richardson. 1994. Lower Devonian coalified sporangia from Shropshire: Salopella Edwards \& Richardson and Tortilicaulis Edwards. Botanical Journal of the Linnean Society 116: 89-110.

Edwards, D., P.A. Selden, J.B. Richardson, and L. Axe. 1995. Coprolites as evidence for plant-animal interaction in Siluro-Devonian terrestrial ecosystems. Nature 377: 329-331.

Edwards, D., G.D. Abbott, and J.A. Raven. 1996. Cuticles of early land plants: A palaeoecophysiological evaluation. In Plant cuticles: An integrated functional approach, ed. G. Kerstiens, 1-32. Oxford: Bios Scientific Publishers.

Edwards, D., L. Axe, and J.G. Duckett. 2003. Diversity in conducting cells in early land plants and comparisons with extant bryophytes. Botanical Journal of the Linnean Society 141: 297-347.

Edwards, D., P.A. Selden, and L. Axe. 2012. Selective feeding in an Early Devonian terrestrial ecosystem. Palaios 27: 509-522.

Edwards, D., L. Axe, and R. Honegger. 2013. Contributions to the diversity in cryptogamic covers in the mid-Palaeozoic: 'Nematothallus' revisited. Botanical Journal of the Linnean Society 173: 505-534. https://doi.org/10.1111/boj.12119.

Edwards, D., P. Kenrick, and L. Dolan. 2017. History and contemporary significant of the Rhynie cherts-our earliest preserved terrestrial ecosystem. Philosophical Transactions of the Royal Society (B: Biological Sciences) 373: 20160489.

Edwards, D., R. Honegger, L. Axe, and J.L. Morris. 2018. Anatomically preserved Silurian 'nematophytes' from the Welsh Borderland (UK). Botanical Journal of the Linnean Society 187: 272-291. https://doi.org/10.1093/botlinnean/boy022.

Habgood, K.S. 2000. Integrated approaches to the cycling of primary produce in early terrestrial ecosystems. Unpublished $\mathrm{PhD}$ thesis. Cardiff: Cardiff University.

Habgood, K.S., H. Hass, and H. Kerp. 2004. Evidence for an early terrestrial food web: Coprolites from the Early Devonian Rhynie chert. Transactions of the Royal Society of Edinburgh, Earth Sciences 94: 371-389.

Honegger, R., D. Edwards, and L. Axe. 2013. The earliest records of internally stratified cyanobacterial and algal lichens from the Lower Devonian of the Welsh Borderland. New Phytologist 197: 264-275.

Honegger, R., D. Edwards, L. Axe, and C. Strullu-Derrien. 2017. Fertile Prototaxites taiti: A basal ascomycete with inoperculate, polysporous asci lacking crosiers. Philosophical Transactions of the Royal Society of London (B: Biological Sciences) 373: 20170146

Hueber, F.M. 2001. Rotted wood-alga-fungus: The history and life of Prototaxites Dawson 1859. Review of Palaeobotany and Palynology 116: 123-158.

Krings, M., C.J. Harper, and E.L. Taylor. 2017. Fungi and fungal interactions in the Rhynie chert: A review of the evidence, with the description of Perexiflasca tayloriana gen. et sp. nov. Philosophical Transactions of the Royal Society (B: Biological Sciences) 373: 20160500.

Labandeira, C.C., B.S. Beall, and F.M. Hueber. 1988. Early insect diversification: Evidence from a Lower Devonian bristletail from Quebec. Science 242: 913-916.

Lang, W.H. 1937. On the plant-remains from the Downtonian of England and Wales. Philosophical Transactions of the Royal Society (B: Biological Sciences) 227: 245-291.

Morris, J.L., D. Edwards, J.B. Richardson, L. Axe, and K.L. Davies. 2011. New plant taxa from the Lower Devonian (Lochkovian) of the Welsh Borderland, with a hypothesis on the relationship 
between hilate and trilete spore producers. Review of Palaeobotany and Palynology 167: 51-81.

Morris, J.L., D. Edwards, and J.B. Richardson. 2018. The advantages and frustrations of a plant Lagerstätte as illustrated by a new taxon from the Lower Devonian of the Welsh Borderland, UK. In Transformative paleobotany: Papers to commemorate the life and legacy of Thomas N. Taylor, ed. M. Krings, C.J. Harper, N.R. Cúneo, and G.W. Rothwell, 49-67. London: Elsevier.

Poinar, G., H. Kerp, and H. Hass. 2008. Palaeonema phyticum gen. n., sp. n. (Nematoda: Palaeonematidae fam. n.), a Devonian nematode associated with early land plants. Nematology 10 : 9-14.

Richardson, J.B., and D.C. McGregor. 1986. Silurian and Devonian spore zones of the Old Red Sandstone Continent and adjacent regions. Bulletin of the Geological Survey of Canada 364: 1-79.
Rubinstein, C.V., P. Gerrienne, G.S. De la Puente, R.A. Astini, and P. Steemans. 2010. Early Middle Ordovician evidence for land plants in Argentina (eastern Gondwana). New Phytologist 188: 365-369.

Schneider, K., C. Renker, and M. Maraun. 2005. Oribatid mite (Acari, Oribatida) feeding on ectomycorrhizal fungi. Mycorrhiza 16: $67-72$.

Shear, W.A., and G.D. Edgecombe. 2010. The geological record and phylogeny of the Myriapoda. Arthropod Structure and Development 39: 174-190.

Strother, P.K. 2010. Thalloid carbonaceous incrustations and the asynchronous evolution of embryophyte characters during the Early Paleozoic. International Journal of Coal Geology 83: 154-161.

Taylor, T.N., M. Krings, and E.L. Taylor. 2015. Fossil fungi, 1st ed. Amsterdam: Elsevier. 